with a watery mixture of sand and salt, known as sabakha, which often has a crust over salty sludge. In the October issue of the Geographical Journal, Dr. J. Ball discusses in detail his proposal to utilise this depression for power production. He suggests the construction of four pipe lines to bring in the waters of the Mediterranean, which lies about fiftysix kilometres to the north. For a lake area of 13,500 square kilometres with a level below the sea of 50 metres, he calculates a permissible influx of $56,700,000$ cubic metres a day. The level would be maintained by the heavy loss of water due to evaporation, which he calculates at $4 \cdot 6$ millimetres a day where the rainfall is not more than 20 millimetres a year. This process would, of course, lead to increasing salinity of the lake and the eventual filling up of the depression by saline deposits, but Dr. Ball calculates that this would not occur for many centuries. His plan foresees the gradual formation of a lake of the maximum depths extending over nearly two centuries. Dr. Ball has worked out his scheme in much detail and gives all the figures in his paper. It should be noted that the distance over which the power would need to be transmitted to the Nile delta is about 560 miles.

\section{Ellsworth Antarctic Expedition}

ONE of the major problems of the antarctic, the relation between the Ross Sea and the Weddell Sea, is the objective of the Ellsworth expedition which has sailed for the Ross Sea in the Wyatt Earp. The sole aim of Mr. L. Ellsworth and Mr. B. Balchen is to fly from the Bay of Whales, early in January, across to the Wilhelm Barrier in the south of the Weddell Sea on a course that will take them within about four hundred miles of the pole on the Pacific side. The Geographical Journal of November gives some details of the expedition. No landing will be made in the Weddell Sea and the party will return at once to the base. The double journey of a total of 2,900 miles should be made in about twenty hours. A Northrop low-wing monoplane has been built for the flight and tested in Canada and Norway. It is not contemplated that more than a week will be spent in the Ross Sea, though a year's supplies are being carried.

\section{Journal of the University of Bombay}

THIs journal is mainly intended for the publication of the results of researches carried out by the teachers and students of the University of Bombay. It is to be issued six times in the year; the parts issued in January and July are to be devoted to history, economics and sociology, the part for March to biology, the part for September to the physical sciences and mathematics, and the parts for May and November to arts and law. We have received the biological part, dated March 1933, which contains thirteen papers, three on botanical subjects, seven on zoology, and others on the rabbit ovulation test for pregnancy, the characters of the Indian pelvis and the biophysics and biochemistry of the blood in tuberculosis. The zoological papers include descriptions of the vascular system of the sea-slug, Oncidium, the skeleton of the globe-fish, Tetrodon, the reproductive and excretory organs of Thalassema bombayensis, and of the history of the thymus of the plaice. This last investigation was carried out in the University of Liverpool, but the others represent work done in Bombay. The papers are illustrated by line drawings in the text and by plates. Several of the line drawings are somewhat crudely executed; but the fault in some cases is in the original drawings, though in others a smoother paper would probably be more suitable for clear reproduction of details. At the end of the part are abstracts of four M.Sc. theses in Bombay for the year 1931-32.

\section{Disappearance of 'Submerged Forests'}

THE disappearance of the last traces of the 'submerged forests' at the old peat beds of the Lancashire and Cheshire coast, where the tides have now washed away all trace of the prehistoric tree stumps that littered the shores so abundantly at West Kirby, Hoylake, Dove Point and Leasowe on the Cheshire shore, and Hightown and Blundellsands on the Lancashire shore, has robbed geologists in particular of one of the most extensive of these collections on the British coasts. The submerged forests near Liverpool have perhaps been more closely studied than any others of these remains, and a generation ago the stumps that littered parts of the coast numbered many hundreds and were widely known. None now remains. Numerous remains of the antler deer (Cervus elaphus), wild oxen (Bos longifrons and $B$. primigenius), the metacarpel of a roe deer (Capreolus caprcea) and of domestic animals as the horse, dog, and in 1873 the skull of Homo sapiens, have been taken from these submerged forests in the Liverpool area. Smith (Proc. Historic Soc. Lancs. and Cheshire, 18) describes an unusually fine pair of horns of the larger form of the red deer taken at Leasowe, 1863, each antler forty inches long and the pair measuring seven feet from tip to tip, while Liverpool Museum received a large number from Hightown in 1916 (Proc. Liverpool Geol. Soc., 14). Roots of Osmunda and shells of Buccinum, Turritella, Scribicularia, Tellina and Nutica have also been obtained from the blue silt below the peat beds.

Botanical Society and Exchange Club of the British Isles

UNDER the editorship of the new secretary, W. $\mathrm{H}$. Pearsall, this report (Arbroath: T. Buncle and Co, 1933) contains a mass of interesting information relating to British field botany. Lists and critical notes on many new varieties, subspecies and adventive species, and new county records are given. Articles on critical species and genera are contributed by the late Dr. Drabble on "Ranunculus bulbosus and its varieties in Great Britain" and "Valeriana officinalis and its allies in Great Britain". Mr. Pearsall gives a revision of the genus Zannichellia and new keys and descriptions of the British species of Carex. A. E. Wade contributes notes on the genus Myosotis and J. S. L. Gilmour writes on "The Taxonomy of Plants intermediate between Medicago 